Revista de la red interuniversitaria de estudios sobre las literaturas rioplatenses contemporáneas en Francia

$14 \mid 2016$

Levrero

\title{
Burdeos. Gestos de contemporaneidad.
}

\section{Carolina Bartalini}

\section{OpenEdition}

\section{Journals}

Edición electrónica

URL: http://journals.openedition.org/lirico/2230

DOI: $10.4000 /$ lirico.2230

ISSN: 2262-8339

Editor

Réseau interuniversitaire d'étude des littératures contemporaines du Río de la Plata

Referencia electrónica

Carolina Bartalini, «Burdeos. Gestos de contemporaneidad. », Cuadernos LIRICO [En línea], 14 | 2016,

Puesto en línea el 07 junio 2016, consultado el 01 mayo 2019. URL : http://journals.openedition.org/ lirico/2230 ; DOl : 10.4000/lirico.2230

Este documento fue generado automáticamente el 1 mayo 2019.

\section{(c) $(1) \Theta \Theta$}

Cuadernos LIRICO está distribuido bajo una Licencia Creative Commons Atribución-NoComercialSinDerivar 4.0 Internacional. 


\title{
Burdeos. Gestos de contemporaneidad.
}

\author{
Carolina Bartalini
}

I

Hay un dibujo que se va formando, lleno de palabras, o es tal vez un discurso cuyas palabras se ordenan formando un dibujo. Al principio todo es confuso y oscuro, luego aparece un bulto que se va revelando como integrado por capas, algo como telas dibujadas, pegoteadas entre sí, húmedas y apelotonadas, y debo tener la paciencia de irlas despegando una a una sin que se dañen; esto puede llevar mucho tiempo o incluso no suceder nunca; yo no soy realmente quien opera sino apenas un espectador casi pasivo : mi única actividad consiste en mantener la atención puesta en ese transcurrir, tratando de eliminar interferencias.

Mario Levrero, "Los muertos".

1 En el año 2013 se publica por primera vez Burdeos, 1972, un texto que hasta ese momento permanecía inédito dentro del archivo Levrero. A primera vista todo indicaría que las páginas que leemos fueran una suerte de diario íntimo final o las memorias de un autor que elige concentrarse en un momento clave de su vida para volver a recordar el resto. El texto potencia su valor por su condición póstuma y por la novedad autobiográfica que supone para quienes buscan esos restos de humanidad en la literatura (o viceversa). Escrito en el año 2003, luego de La novela luminosa, Burdeos ${ }^{1}$ se vuelve un objeto aurático : un texto que es reconocido como autobiográfico por fuera de sí, observado a priori como un relato testimonial, un documento, la reliquia intelectual de un escritor que muere repentinamente un año después de su última anotación ${ }^{2}$. El halo de la curiosidad y el fetiche de la intimidad hecha pública rozan la lectura de Burdeos, cuya edición lo propone de esta manera en detrimento de la ficción. Por el contrario, la única finalidad reconocible del texto y del autor es «contar esa larga historia $»^{3}$, la de su breve viaje a Francia, un relato acabado que solo busca la plenitud a través de la luz de la palabra. Un relato iniciático narrado treinta años después y de manera oblicua en esta suerte de diario des-temporal que pretende capturar en su presente las reminiscencias del pasado a 
través de la escritura como trance y ritual, la escritura como experiencia, origen y culminación.

2 La edición de Burdeos ${ }^{4}$ obedece a una decisión editorial así como también su yuxtaposición con Diario de una canalla. Ambos textos corresponden a momentos diferentes de escritura, a espacialidades distintas y a atmosferas subjetivas disonantes : mientras que el Diario de un canalla fue escrito en Buenos Aires durante el período en que Jorge Varlotta se ocupaba de la dirección de las revistas de crucigramas de su amigo Jaime Poniachik entre 1985 y 1987 ; Burdeos fue redactado en Montevideo en el año 2003 luego de finalizar el volumen de La novela luminosa y el simultáneo período de la beca que la Fundación Guggenheim le otorgara en el año 2000. Diario de un canalla es un texto en presente, un diario de redención que pretende exorcizar el fantasma de la ficción no escrita a través de la escritura perlocutiva ${ }^{5}$. Burdeos, por el contrario, es y no es un diario, toca y no toca el presente, y se aleja de la intención sanadora de la escritura como ejercicio, para arribar a la condición del relato como historia. La peripecia de Diario de un canalla comprende un mes de vida, y un mes de escritura, Burdeos se escribe en veinte días pero su tiempo es otro, el recuerdo de los meses vividos en Francia, tres décadas atrás. Con Diario de un canalla, como afirma Cristina Siscar, Levrero inaugura la "tetralogía voluntaria", que Burdeos vendría a culminar. ${ }^{6}$ En el medio quedarían Apuntes bonaerenses, El discurso vacío y La novela luminosa, una zona de vínculo entre Diario de un canalla y Burdeos ya que en el primero Levrero comienza mencionando la frustración de su incompletitud -la de $L a$ Novela luminosa- y Burdeos, creemos, se realiza gracias a su culminación. En este transcurrir el autor arriba al reconocimiento de una forma de escritura que deja de luchar contra el espectro de la Literatura, contra el prejuicio de marginalidad y la ausencia de ambiciones artísticas para llegar, en Burdeos, a la indescirnibilidad entre ficción y experiencia, entre pasado y presente y entre la literatura y la vida.

3 A pesar de estas distancias, los textos conviven. Son formas de escritura de un sujeto atribulado, ya sea por el exceso de trabajo "no literario" y el exilio laboral en Diario de un canalla, o por la soledad -otra forma del exilio, un auto-exilio- y la irrupción de las imágenes de ese pasado conmovedor en Burdeos. Son formas de escritura de introspección, aunque esto sea más bien una constante en la narrativa del autor que los supera y los incluye. Son relatos "irruptivos" : ambos fueron escritos en pocas semanas y cuentan más que un período de tiempo una forma de estar, una atmósfera cotidiana y personal (Diario de un canalla está fechado entre diciembre de 1986 y enero de 1987; Burdeos, en septiembre de 2003). Son dinámicas de acercamiento a la escritura, como interpreta Marcial Souto en el prólogo al volumen ambos son « fruto de dos grandes aventuras vitales de Jorge Varlotta, una por amor y otra por necesidad ${ }^{7}$. Aunque en principio parezca claro, cabría preguntarse, sin embargo, cuál texto correspondería a cada aventura. En todo caso, ambos hablan de experiencias fallidas, de búsquedas, hallazgos y nuevas aperturas (de nuevo, otra constante que los acerca y los excede). Ambos textos, entonces, se presentan ahora contiguos, contemporáneos.

4 En relación a las razones editoriales que llevaron a esta edición conjunta de Diario de un canalla / Burdeos, 1972 podríamos arriesgar tal vez un motivo comercial que se suma a las coincidencias literarias antes mencionadas. La publicación demuestra la atención de la editorial por las preferencias de un público que se acerca a la obra de Levrero desde sus textos "más autobiográficos", preferencias que dan cuenta de las dinámicas de lectura, creación y circulación en los últimos años. Pero a pesar de este hecho, que nos inserta en un pacto de lectura particular, es innegable que la publicación de este volumen permite la 
lectura prima de Burdeos y la relectura (o lectura para quienes en ese momento recién nos iniciábamos en el código escrito) del Diario de un canalla, editado en el desaparecido $\mathrm{El}$ Portero y el otro de 1992, aún sin re-edición completa. Llama la atención por tanto que de ese libro de relatos diversos, de géneros y estilos disonantes, trascienda al mainstream de los anaqueles editoriales sólo Diario de un canalla, y no -por dar otro ejemplo que podría singularmente agregarse a la serie- "Apuntes bonaerenses", o bien el libro entero. El problema no deja de existir pero se vuelve menor si tomamos en consideración que el libro bajo el atento cuidado Nicolás Varlotta -el hijo del autor- se nos ofrece finalmente a la lectura y de manera fiel a un original que resultaría inaccesible de otra manera ${ }^{8}$.

5 Sin embargo, para nuestra reflexión sería prudente señalar que esta yuxtaposición (y considerando también que toda selección implica ausencia y omisión) genera dos hipótesis tentativas : en primer lugar, Burdeos se lee como un texto autobiográfico debido al pacto de lectura referencial que los criterios editoriales nos incitan a realizar. En segundo lugar, en esta situación Burdeos es contiguo a Diario de un canalla, y entonces su contemporáneo, ya que la nebulosa en la que se ubican los textos póstumos implica necesariamente una datación pública que los determine desde otros parámetros, reflexión que podríamos extender a todos los textos si nos preocupara la crítica genealógica. En definitiva, lo que pretendemos formular es esta dimensión confusa que hace de Burdeos un escrito híbrido, indiscernible en su propia textualidad entre la ficción y el testimonio, y entre los tiempos que la misma obra radicalmente complejiza, o en otras palabras, entre el tiempo de escritura, el tiempo del relato y el tiempo de la edición.

\section{II}

Casi puedo acariciar ese terciopelo, siguiendo el contorno de la flor con la yema de los dedos ; y ya no es el olor, ni el discurso, ni el dibujo, sino tal vez el tacto, o más probablemente otra cosa que por ahora no puedo definir, apoyada en una impresión de origen táctil, que también se integra al cuadro general de la sala de piano. La flor de lis repetida no es el único dibujo; hay otros trazos, adornos, arabescos, en un gris menos contrastado. Por momentos esos trazos parecen formas de escritura, pero no son esas las palabras del discurso, o si coinciden con estas no puedo saberlo, no conozco el significado. Las palabras del discurso son formuladas mentalmente, y solo adquieren cuerpo y sentido preciso cuando se ajustan a las sugerencias de los dibujos y de los olores; pero así y todo no sería capaz de repetirlas: solo ahora, mucho más tarde, pudo tratar de reconstruirlas con otras palabras para indicar el clima del discurso, no las palabras mismas ni su significado exacto, que siempre se me pierden.

Mario Levrero, "Los muertos".

6 La escritura auto-referencial no constituye en la narrativa de Mario Levrero sólo un espacio acotado a sus libros autobiográficos ${ }^{9}$, la exploración de los mecanismos literarios y la exhibición de la escritura misma como objeto de referencia y reflexión es incluso bastante usual en textos habitualmente considerados como ficciones netas ( Desplazamientos, Dejen todo en mis manos, El alma de Gardel, entre otros). El uso de la primera persona y la presencia de reflexiones sobre la naturaleza de la escritura no son criterios para discernir -en el caso de Levrero- si un texto es o no es autobiográfico, puesto que como constante desdibuja sus posibilidades de identidad con el sujeto que escribe -en el caso de la primera persona- y el rasgo propio de los textos autobiográficos, la metareflexión sobre la escritura, se vuelve habitual a lo largo de toda su obra. 
7 La distinción entre autobiografía y ficción es un problema que ha sido abordado desde diversas disciplinas. El conflicto central radica en establecer qué es realidad y qué es imaginación, o dicho de otra forma, qué es lo cierto y qué es lo inventado, cómo y quién puede establecer el carácter verídico de los hechos narrados por un sujeto, hasta qué punto la realidad es algo absoluto, y en qué medida la primera persona que enuncia se corresponde con el cuerpo real del enunciado. Por otro lado, también existen diferencias entre distintos géneros emparentados con la escritura de la vida: autobiografía, memorias, diarios, epistolarios, novelas autobiográficas, etcétera. Para Philippe Lejeune lo que resume los problemas de la autobiografía como género es el nombre propio : « en este nombre se resume toda la existencia de lo que llamamos el autor : única señal en el texto de una realidad extra-textual indudable, que envía a una persona real, la cual exige de esa manera que se le atribuya, en última instancia, la responsabilidad de la enunciación de todo el texto escrito $»^{10}$. De esta manera, lo que debe coincidir para Lejeune es la identidad de nombre entre autor, narrador y personaje, incluso cuando haya seudónimos de por medio. La firma Levrero/Varlotta, que alterna entre los dos apellidos del autor -filiación materna y paterna alternada-, no modificaría esta identidad del nombre con el sujeto corporal sino que la volvería tan solo un poco más compleja. La dificultad se suscita cuando no hay marcas nominales internas al texto, pero esto no sucede en Burdeos porque para poder explicar la historia de los nombres duplicados el narrador debe acudir a mencionarse y develar la genealogía de sus firmas :

(...) debo aclarar que mi nombre oficial es Jorge Varlotta. Fue justamente Antoinette la primera en llamarme habitualmente Mario. Mejor dicho, Marió. (...) La adopción del nombre Mario como mi nombre habitual -no ya Marió- se hizo con el tiempo más frecuente y el Jorge pasó a segundo plano. Esto sucedió porque mi mundo, el mundo de mis amigos y conocidos, se fue nutriendo cada vez más con personas provenientes del ambiente literario, desde los lectores hasta los alumnos. Sólo unos pocos amigos más bien antiguos me siguen llamando Jorge. Y yo no dejo de sentir, nunca, ese Mario como una apropiación indebida. Es como si me aprovechara de los méritos de otro, de ese que no tiene nombre y me dicta lo que debo escribir ${ }^{11}$.

8 Asimismo, la cuestión del nombre se vuelve cada vez más compleja cuando al final de esta explicación el narrador indica : «pero siempre he tratado de dejar en claro que ése que escribe no soy exactamente yo $»^{12}$, como si todo lo dicho previamente no tuviera más sentido que poder introducir una anécdota, la historia de la semejanza física entre el creador Dupont, exactamente igual al narrador, y su identidad nominal con el marido de Antoinette (aunque también, claro, desnaturalizar la noción de igualdad, y proponer la del doble). En esta anécdota el narrador pasa a llamarse Dupont por contexto (los obreros lo llaman así por ser el hombre que abre la puerta del domicilio de Madame Dupont, o sea Antoinette), y de esta forma casual el narrador se convierte ya no sólo físicamente sino también nominalmente -y simbólicamente- en Dupont, uno de los hechos que acelera su huida de Francia. Es necesario entonces explicarse, dar cuenta de su nombre y de su seudónimo, develar el origen y al mismo tiempo exponerlo como un sentido y un sinsentido. El nombre ya totalmente desfigurado hacia el interior del texto permite establecer el pacto biográfico hacia su exterior : la coincidencia del narrador, personaje y autor no dejan, en primera instancia, dudas al respecto. Sin embargo, es el mismo Lejeune quien indica que « uno es siempre varias personas cuando escribe, incluso cuando uno escribe solo, incluso cuando escribe su propia vida $»^{13}$. 
El caso de Pierre Dupont es precisamente el ejemplo que utiliza Michael Foucault en su célebre conferencia ¿Qué es un autor?, para explicar la función que desempeña el nombre autoral en el estatuto de un discurso :

(...) un nombre de autor no es simplemente un elemento en un discurso (que puede ser sujeto o complemento, que puede reemplazarse por un pronombre, etc.) ; ejerce un cierto papel con relación al discurso : asegura una función clasificatoria; tal nombre permite reagrupar un cierto número de textos, delimitarlos, excluir algunos, oponerlos a otros.(...) En una palabra, el nombre de autor funciona para caracterizar un cierto modo de ser del discurso : para un discurso, el hecho de tener un nombre de autor, el hecho de poder decir 'esto fue escrito por Fulano de Tal', 'Fulano de Tal es el autor de esto', indica que dicho discurso no es una palabra cotidiana, indiferente, una palabra que se va, que flota y pasa, una palabra que puede consumirse inmediatamente, sino que se trata de una palabra que debe recibirse de cierto modo y que debe recibir, en una cultura dada, un cierto estatuto ${ }^{14}$.

10 En una lectura levreriana esta coincidencia podría devenir en sentidos más significativos que los aparentes, aunque Dupont sea un apellido habitual en Francia. Creemos que la duplicación nominal, y sus identidades, puede parecer suficiente para asociar un relato con una vida, sin embargo, la ficción también juega con materiales reales, y muchas veces pretende confundir y engañar, utilizando coincidencias, y amplificándolas. Pensamos que a priori el pacto autobiográfico en Burdeos se produce por otros rasgos que asocian ese texto con las "memorias" o con el "diario íntimo". La coincidencia del nombre del narrador con el del autor podría ser un invento, una mentira, sin embargo, los datos pragmáticos que rodean al texto presuponen una lectura orientada hacia lo autobiográfico que antecede a la explicación de los nombres duplicados del final del libro. Ahora bien, sin este orden, sin estas marcas de enunciación, ¿qué distingue a Burdeos de un relato ficcional, si pretendemos no caer en la verificación empírica de los hechos referidos?

11 Tanto la ficción como la autobiografía se proponen como un pacto social, un código que como la lengua- se hereda y modifica constantemente. No hay propiedades textuales que permitan identificar de manera directa un fragmento discursivo con la ficcionalidad o la autobiografía ; aunque sí hay marcas textuales y contextuales -señales convencionales del tipo "novela", "diario", determinadas fórmulas introductorias y finales ${ }^{15}$, ciertas estructuras características o la inclusión del texto en determinada editorial o colecciónque operan como marcos de significación, pautas de lectura que alteran la "pureza" de la materialidad del texto en cuestión.

12 Como sabemos, a lo largo de su obra Mario Levrero se ha empecinado por mostrar develar- esos matices de ambigüedad entre cada tipo de "situación discursiva", de manera que la exposición del artificio produzca la duda sobre una factible clasificación genérica en términos estructuralistas, e incluso, muchas veces estableciendo contradicciones entre las marcas textuales y contextuales de sus textos. Así lo que escribió de forma directa en otros libros como en El alma de Gardel, por citar un caso, en Burdeos lo observamos no tematizado, de forma, tal vez, más "natural" :

Qué garantía, pues, tendrá mi lector de la fidelidad de este relato que es, él, pura memoria y sólo memoria. Pero qué garantía tenemos, todos, de la fidelidad de un libro de Historia, o siquiera de las noticias de un periódico. Si yo me veo obligado a dudar a cada momento de mi propio relato, sabedor de mi honestidad pero desconfiado de los mecanismos de la percepción y del "archivo de datos" de mi 
propia mente, cómo voy a confiar en lo que recibo de manos ajenas, y de gente que, por otra parte, tiene sobrados motivos para engañar ${ }^{16}$. entre los momentos narrados. La narración se organiza canónicamente en pasado, aunque aparezca el presente o el futuro como formas enunciativas, se sabe que es un procedimiento de estilo que no altera el estatuto pasado de los hechos referidos. Esto significaría que no es posible narrar, al menos no de forma lógica, situaciones no sucedidas con un estatuto factual -real o imaginario-, como tampoco relatar el presente, más allá que como artificio. Podríamos decir entonces que el diario, como variante de la autobiografía, trabaja con un pasado inmediatamente anterior al relato. Sin embargo, en Burdeos Levrero opera con un pasado distante como material narrativo, para reconstruir sin decirlo- su propio presente : se muestra el ahora a través de su imagen distorsionada de un tiempo-lugar otro. A través del relato se proyectaría la experiencia del que se escribe a sí mismo en un tiempo dual : pasado y presente confluyen como dos instancias duplicadas en el escribiente que recurre a su memoria como objeto de indagación.

Ahora bien, Burdeos se presenta como un diario íntimo : está fechado en cada entrada, es continúo, habla del sujeto y de la escritura, refiere hechos aparentemente reales, autornarrador y protagonista confluyen en la imagen de una sola persona ${ }^{17}$. Sin embargo, el tiempo de la experiencia narrada se retrotrae más de treinta años atrás. Es un relato autobiográfico que transita los lugares comunes del género pero los trastoca en una duplicación hegemónica del tiempo y del sujeto autor. A la vez, esta duplicación produce un efecto de des-temporalidad en tanto que el tiempo lineal, causal, el tiempo de la lógica se diluye en la creación de un tiempo otro, un tiempo que hace contemporáneos a los dos sujetos, a los dos tiempos y a los dos relatos (estas duplicaciones se proyectarán a su vez en una serie de personajes y escenas dobladas en la historia). Un clima particular de angustia y desilusión se perfila desde el relato contado, pero lo es también del tiempo presente de la narración, el clima es la forma en la que se unen las dimensiones del discurso, y para Levrero su máxima ambición : « Atrás de la imagen todavía está otra cosa : el clima, que me parece lo fundamental. Porque la imagen puede ser otra, igual que la palabra, pero lo que yo trato de reproducir es el clima de lo que estoy viviendo en ese momento $»^{18}$.

\section{III}

Cómo no soñar con museos, cuando uno mismo es una especie de museo.

Así los dibujos y las palabras me llevan como por piezas contiguas que sin embargo son la misma pieza ; sin duda una habitación interior, algo mío, expresándose en diferentes imágenes y sensaciones. Y así, sintiendo en mí una cierta excitación fue recobrando el clima y las imágenes del sueño del supermercado, porque allí había un museo y ese museo tenía mucho de la pieza del extranjero -la sala de mis tías. Mario Levrero, "Los muertos".

En la idea del museo se expresa la pervivencia a-temporal y simultánea de tiempos diversos. Esos tiempos conviven en el objeto y en su representación, así, en el museo como en la escritura rememorativa, se forma una constelación des-temporal que revive en la experiencia de la contemplación y su recorrido. Así también como en el museo, en la escritura de un diario de rememoración, como es el caso de Burdeos, se configuran dualidades. El objeto y su representación no son iguales pero parecen ser uno. El hombre 
y el escriba pertenecen a tiempos distintos pero confluyen en un mismo espacio-tiempo sincronizado por la imagen del observador.

Giorgio Agamben proyecta, en relación al sujeto y su tiempo, que « la contemporaneidad es, pues, una relación singular con el propio tiempo, que adhiere a este y, a la vez, toma su distancia ; más exactamente, es esa relación con el tiempo que adhiere a éste a través de un desfase y un anacronismo $»^{19}$. Lo contemporáneo se propone como un adjetivo absoluto y no relacionante, como un atributo del sujeto que «mantiene la mirada fija en su tiempo, para percibir, no sus luces, sino su oscuridad ». La relación que se expone no es inter-subjetiva sino inter-temporal. Todo tiempo tiene dos caras que conviven aunque habitualmente una se esconda en la otra. El poeta contemporáneo es, para Agamben, quien tiene la capacidad -el don o el coraje- para percibir lo que los demás no pueden observar: la simultaneidad, el absoluto del tiempo en un momento histórico que, se vislumbra eventual.

El sujeto contemporáneo, desde esta óptica, lo es con su tiempo pero por fuera del tiempo (y de su tiempo). Este sujeto resulta entonces contemporáneo de sí mismo, quien convive con su luz y con su oscuridad, y viceversa. "Todos los tiempos son, para quien experimenta su contemporaneidad, oscuros", así la noción de contemporaneidad vislumbrada por Agamben resulta a la vez no solo un don y una fuerza disruptiva sino también, y fundamentalmente, una experiencia. El artista contemporáneo lo es porque vive en su época con clara certidumbre de su época, pero con la capacidad de experimentar y expresar lo no-epocal, lo no-temporal (que no es a-temporal sino precisamente des-temporal). Percibir lo oscuro del tiempo presente es una manera ajena de percibir lo sustancial de uno mismo, las aristas ocultas que, a la vez, por oposición, configuran la luz.

En esta lectura, la experiencia de escritura de Burdeos sería el grado luminoso de una actividad que se vuelca hacia las sombras -su propia oscuridad inherente, la del presente y la del pasado- para recomponer en el ejercicio de su exploración, un halo de luz. Pero no exactamente los hechos, sino las constantes que a través de la escritura del pasado surgen y resurgen en el plano presente, vistas nuevamente y por primera vez en la experiencia de la contemporaneidad con uno mismo. Los dos tiempos -y todo el tiempo- viven en ese presente hipnótico del relato. Lo que se busca es la imagen para reconstruir el clima a través de la mirada hacia lo luminoso o lo oscuro de uno mismo. El resultado : el relato de la imagen, que es la duplicación de uno mismo con cierta distorsión, o verdad, dependiendo de la confianza, la ingenuidad, o el escepticismo del que lea.

Burdeos, 1972 empieza como un diálogo terapéutico (real o inventado ya no nos interesa) y a partir del asombro del interlocutor ( «-¡Burdeos! - exclamó hoy, o mejor dicho ayer, hace unas horas, mi terapeuta-. ¡Burdeos!-repitió-. ¡Y cómo fue que usted, nada menos que usted, fue a dar a Burdeos?») comienza el derrotero de poner en palabras las imágenes que surgían del ensueño. En la pregunta inicial están las claves del asunto : los tiempos se pretenden ordenar en el discurso pero se distorsionan ("hoy", "ayer", "hace unas horas») y la figura del terapeuta, como un oráculo, dirige el trance duplicativo del yo: hay un "usted» y un «nada menos que usted» que parecen irreconciliables. El primero es el sujeto aparente, el que habla desde el presente, sin conocer todavía el reverso de ese momento, la imagen del que escribe el diario. El otro " usted », el que está puesto en duda, es la parte oscura que pugna por mostrar que vivió y que lo sigue haciendo dentro del primero, es decir, el Levrero de 1972. 
¿Es posible ser auto-contemporáneo, contemporáneo de uno mismo, vivir el aquí-ahora, la confluencia del tiempo sin tiempo ? Carl Jung denomina este fenómeno como principio de sincronicidad : « un concepto que configura un punto de vista diametralmente opuesto al de causalidad ». La diferencia radica en la forma en que se perciben los hechos, o más bien, las conexiones que se realizan entre ellos : « el concepto general de sincronicidad en el sentido específico de la coincidencia temporal de dos o más acontecimientos, no relacionados entre sí causalmente, cuyo contenido significativo es idéntico o semejante " ${ }^{20}$. La escritura de la experiencia configura un espacio proclive para la expresión de la contemporaneidad donde uno (el que escribe, el que vive la escritura del recuerdo) se figura en sincronicidad con el otro-uno mismo (el que vivió la referencia de la escritura). Y por lo tanto, esos dos "unos-mismos" se vuelven uno en el instante de la ensoñación, de la remembranza, sin distancias temporales, como si fuera la unificación de dos constelaciones que implotan en el momento en que la palabra, que -en definitiva- es la huella, el resto de la duplicación, de la unión y del tiempo, toma su forma. El efecto, entonces, es la des-temporalización, o un tiempo otro, un cronos absoluto, cerrado y a la vez poroso que vuelve a hacerse pleno cuando la palabra es dicha, es leída, es vivenciada nuevamente en la experiencia del lector. Pero, no cualquier lector, sino aquel que vive intensamente un aquí-ahora con el relato, y que por esto mismo se vuelve su contemporáneo y puede ver la luz y a la vez la oscuridad, lo otro -lo no dicho-, el silencio o la imagen del que escribe y su situación -con sus aristas, luces y sombras. Y así se produce una relación de intimidad, de sobremesa con el cuerpo escrito.

\section{IV}

Y en seguida sentí un tirón imaginario y una tela se despegó con total limpieza de las otras, extendiendo nítidamente su discurso y su dibujo ante mi conciencia, y entonces tuve la certeza de que había vuelto a ser un hombre completo.

Mario Levrero, "Los muertos".

21 Burdeos se compone, como se anuncia al principio, de imágenes hechas con palabras. Segmentos descriptivos que pretenden construir una atmósfera más que un relato o un relato dentro de un clima que une los dos tiempos. Escenas de reiteración -repetición, reflejo distorsionado- en las que la realidad se torna dual, siempre simbiótica entre dos polos yuxtapuestos y complementarios. Así, los dobles proliferan: el tiempo, el espacio, los dos sujetos, los dos « usted », las dos mujeres que saludan con llanto y risas cuando el escritor parte de nuevo al origen; los dos pasajes recogidos por Antoinette en el subterráneo, los dos diarios leídos (Le Monde y Charly Hebdo), las dos ventanas de la habitación, los camioneros asimétricos que bailan el valsecito francés en El Café des routiers («apenas empezó a sonar la música, el pequeño se unió con el grandote y empezaron a bailar; no, no empezaron; salieron del mostrador bailando y bailando se encontraron $»^{21}$ ); esos valses franceses y los tangos « que escuchaba a mis quince años en discos del sexteto de Julio De Caro, grabados quince o dieciséis años antes de que yo naciera $»^{22}$; las dos nostalgias, la alegría y el fracaso, lo vivido y lo no vivido (« la nostalgia del valsecito francés viene mezclada con un cierto fracaso, un fracaso por así decirlo placentero ; fracasa en la alegría que pretende; es una alegría falsa, y que sabe que es falsa. El tango me trae la nostalgia por algo que no viví pero que fue; el valsecito me quiere mostrar algo presente que no es, algo que debería alegrarme pero con un tipo de alegría que no existe, o que no conozco. Lo que podría ser, pero no es, ni será » ${ }^{23}$ ). Las dos monedas -los francos nuevos y viejos-; los dos operarios que instalan el placard en el baño 
(" eran dos, con pinta de payasos $»^{24}$ ); el doble sentido de las palabras - «baiser», " embrasser »-, el malentendido - Angoulême Périgueux »-; los dos idiomas -el español en silencio, el francés que surge del interior-; el plano de Burdeos que no existe (todo mapa es la representación) ; la cara en el espejo, la necesidad de cortarse para ser uno otra vez ( «me planté ante el espejo que había sobre el lavatorio. Vi allí a un desconocido que me odiaba, y busqué rápidamente sobre el estantecito y dentro del placard ALGO con qué destruirme. Algo cortante, preferentemente $\left.\aleph^{25}\right)$; Antoinette feliz en Montevideo, Antoinette pellizcada y flaca en Burdeos, Antoinette despierta y Antoinette sonámbula ; los dos padres de Pascale ; el jardín público de Burdeos y el Parque Rodó ; la avenida o ruta ; la luna al revés : « había aparecido la luna, era enorme, y estaba al revés. Todavía no había visto la luna francesa... Aparentaba un tamaño alrededor del doble de la luna montevideana, y algo estaba mal, fuera de lugar, y me perturbaba sin que supiera por qué. Luego comprendí que estaba al revés, quiero decir, al revés de como yo la veía desde el Hemisferio Sur. Era un cuarto creciente que aparentaba ser menguante $»^{26}$.

Y finalmente, Varlotta y Dupont, Brassens y Gardel, Jorge Varlotta y Mario Levrero, el narrador y su nombre de autor. Como observa Michel Foucault, los rasgos del cuerpo que asocio con el nombre pueden cambiar sin que se pierda su conexión, incluso duplicarse o desaparecer sin que por esto pierda valor o validez el nombre del autor. La función autor ordena, posibilita el discurso. ¿Por qué Burdeos no está firmado por Jorge Varlotta, quien se hace cargo del relato que se cuenta?, ¿por qué habría que creer que Jorge Varlotta y Mario Levrero son la misma persona, realmente la misma persona ? Gardel es amigo de Levrero. Sin embargo, ni el Levrero de Burdeos es el Levrero de Burdeos ni el Gardel de los discos es el Gardel que alguna vez cantó o el Gardel de cada uno ; aunque al mismo tiempo también lo sean y convivan en la imagen-nombre de sí mismos :

Así que Gardel nunca fue Gardel. Hay un débil indicio material de que alguna vez hubo alguien que se hizo llamar Gardel y que crio fama de cantante excepcional. Pero de eso no queda más que ese débil indicio material, más un enorme mito, una gigantesca construcción colectiva. Y personal ; porque Gardel, para mí, es esa voz que sale del disco pero también es la guiñada de mi tío Hugo, joven y peinado a la gomina, cuando de la radio salía la voz de Gardel; y una infinitud de experiencias subjetivas más ${ }^{27}$.

En el nombre propio hay sincronicidad, hay coincidencia de factores disidentes, no causales, yuxtapuestos por el orden del discurso. El efecto de la contemporaneidad es lo indiscernible, tanto en el plano de los tiempos como en la hibridez del relato. La diferencia entre la veracidad de Burdeos y su posible lectura en términos de ficción es proclive al análisis pero no a la certeza, la literatura ya anula esta pretensión. El trayecto entre Diario de un canalla y Burdeos sólo es reconocible en su comparación textual, siendo ambos contemporáneos se iluminan mutuamente. El nombre propio que los firma los ancla en un sentido que puede parecer unívoco pero que es, retomando la idea de Agamben, la función que establece el polo de oscuridad, la que los asocia con tiempos que no les pertenecen.

La escritura de Burdeos responde a una búsqueda empecinada por encontrar en el hilo del discurso lo que vive interiormente. Burdeos, recordemos, comienza con la escena de un reloj detenido : hay que repararlo, trabajar atentamente con el destornillador, exclamar varias veces el mismo sonido hasta que el reloj pueda volver a ponerse en movimiento. Así, la escritura, así el recuerdo, en Burdeos. 


\section{BIBLIOGRAFÍA}

Bibliografía

Agamben, Giorgio. “Qué es lo contemporáneo ?”. En Desnudez. Traducción de Cristina Sardoy. Buenos Aires : Adriana Hidalgo, 2011.

Austin, John L. Cómo hacer cosas con palabras : Palabras y acciones. Barcelona : Paidós, 1982.

Domínguez, Carlos María. "Si lo que escribo puede ayudar a alguien creo que mi vida está más que justificada”. En Elvio Gandolfo (comp.) Mario Levrero, un silencio menos. Buenos Aires : Mansalva, 2013.

Foucault, Michel. ¿Qué es un autor? Traducción de Silvio Mattoni. Buenos Aires : El cuenco de Plata, 2010.

Jung, Carl G. La interpretación de la naturaleza y la psique. La sincronicidad como un principio de conexión acausal. Traducción de Haraldo Kahnemann. Buenos Aires : Paidós, 1984.

Lejeune, Philippe. "La autobiografía de los que no escriben". En El pacto autobiográfico y otros estudios, Madrid: Megazul-Encymion, 1994.

Levrero, Mario. Diario de un canalla. Burdeos, 1972. Buenos Aires : Mondadori, 2013.

Levrero, Mario. El alma de Gardel. Buenos Aires : Mondadori, 2012.

Levrero, Mario. El discurso vacío. Buenos Aires : Mondadori, 2011.

Levrero, Mario. “Los muertos”. En Espacios Libres. Buenos Aires/Montevideo : Puntosur, 1987, pp. 245-276.

Pereira, Luis. "Yo nunca he escrito nada que no haya vivido". En Elvio Gandolfo (comp.) Mario Levrero, un silencio menos. Buenos Aires : Mansalva, 2013.

Siscar, Cristina. "Levrero personaje o la creación de sí mismo. Sobre los diarios de Mario Levrero". Carolina Bartalini (ed.) Escribir Levrero. Artículos encontrados sobre Jorge Mario Varlotta Levrero y su literatura. Buenos Aires : Eduntref, 2016.

Souto, Marcial. "Prólogo". En Diario de un canalla. Burdeos, 1972. Buenos Aires : Mondadori, 2013 pp. 7-13.

\section{NOTAS}

1. Mario Levrero, "Burdeos, 1972". En Diario de un canalla. Burdeos, 1972. Buenos Aires : Mondadori, 2013, p. 148. A partir de este momento será mencionado como Burdeos.

2. La última entrada de Burdeos, 1972 corresponde a septiembre de 2003, Mario Levrero fallece el 30 de agosto de 2004.

3. Mario Levrero, Burdeos, óp. cit., p. 84.

4. Utilizaremos las cursivas para referirnos a cada uno de estos textos por separado, en tanto los consideramos autónomos y no partes de un texto mayor, entendiendo, entonces que la publicación conjunta no representa una unidad, aunque los textos sí convivan perfectamente e incluso expongan rasgos en común. 
5. Me refiero a "escritura perlocutiva" siguiendo la teoría de los actos de habla de John Austin. En este sentido, la perlocutividad se refiere a las consecuencias o los efectos que producen los enunciados ilocutivos en el otro, en el interlocutor. En este caso, considero que Burdeos se manifiesta como escritura perlocutiva puesto que tiene una intencionalidad manifiesta de modificar al sujeto escribiente y sus efectos, a su vez, se verifican en éste y en su escritura misma. Cfr. Austin, John L. Cómo hacer cosas con palabras : Palabras y acciones. Barcelona : Paidós, 1982.

6. Cristina Siscar, "Levrero personaje o la creación de sí mismo. Sobre los diarios de Mario Levrero”. En Carolina Bartalini (comp.) Escribir Levrero. Artículos encontrados sobre la literatura de Jorge Mario Varlotta Levrero. Buenos Aires : Eduntref, 2016.

7. Marcial Souto, "Prólogo". En Diario de un canalla. Burdeos, 1972. op. cit., p. 7.

8. De acuerdo con Nicolás Varlotta, con quien hemos conversado sobre este aspecto, la tarea curatorial consistió en mantener la textualidad del original frente a las modificaciones sugeridas por la editorial. La publicación de Burdeos fue pautada en el año 2008, cuando se firmó el contrato con Random-House Mondadori para que se hiciera cargo de las ediciones y reediciones de la obra de Levrero en España y Latinoamérica.

9. Consideramos, como hemos mencionado previamente, dentro de las variantes genéricas de la obra de Levrero, una zona dedicada a la exploración del yo y explicitada de esa manera. En orden cronológico de publicación, esta "tetralogía voluntaria", como la enuncia Cristina Siscar, estaría compuesta por: Diario de un canalla, El discurso vacío, La novela luminosa y Burdeos, 1972. Sin embargo, aunque no sea el propósito de este artículo indagar en esta serie como tal, afirmamos que hay otros textos que pueden plenamente incorporarse a la secuencia : "Apuntes de un voyeur melancólico", publicado en Espacios libres (1987), los “Apuntes bonaerenses" aparecidos públicamente en 1992 junto con "Diario de un canalla" en el libro El portero y el otro. Y otros textos que la rozan, como por ejemplo algunas de las Irrupciones, publicadas semanalmente en la Revista Posdata entre febrero de 1996 y junio del 2000, compiladas luego en formato libro en 2001.

10. Philippe Lejeune, "La autobiografía de los que no escriben". En El pacto autobiográfico y otros estudios, Madrid, Megazul-Encymion, 1994, p. 60.

11. Mario Levrero, Burdeos, óp. cit., p. 169.

12. Ibíd.

13. Philippe Lejeune, "La autobiografía de los que no escriben", op. cit., p. 320

14. Michel Foucault, ¿Qué es un autor? Traducción de Silvio Mattoni. Buenos Aires : El cuenco de Plata, 2010.

15. Incluso las selecciones de fragmentos de los textos para las contratapas en las cuales aparecen frases o palabras que remiten a alguna de estas dos polaridades. En este caso, la contratapa incluye un fragmento de Diario de un canalla que incluye los términos: "escribo", "уо", "autoconstrucción", "mí mismo", "vida". Incluso la gran frase de este texto "Esto no es una novela, carajo. Me estoy jugando la vida », remite y afecta necesariamente la lectura del libro completo para cualquier tipo de lector.

16. Mario Levrero, El alma de Gardel. Buenos Aires : Mondadori, 2012, p. 115.

17. Cfr. Philippe Lejeune, El pacto autobiográfico y otros estudios, óp. cit.

18. Carlos María Domínguez, "Si lo que escribo puede ayudar a alguien creo que mi vida está más que justificada", entrevista a Mario Levrero (1988). En Elvio Gandolfo (comp.), Mario Levrero, un silencio menos, óp. cit., p. 53. El subrayado es mío.

19. Giorgio Agamben, “¿Qué es lo contemporáneo ?”. En Desnudez. Traducción de Cristina Sardoy. Buenos Aires : Adriana Hidalgo, 2011.

20. Carl G Jung, La interpretación de la naturaleza y la psique. La sincronicidad como un principio de conexión acausal. Traducción de Haraldo Kahnemann. Buenos Aires : Paidós, 1984, p. 35.

21. Mario Levrero, Burdeos, óp. cit., p. 94.

22. Ibíd., p. 93.

23. Ibíd., p. 93-94. 
24. Ibíd., p. 129.

25. Ibíd., p. 106. El subrayado es mío.

26. Ibíd., p. 101.

27. Ibíd., p. 141.

\section{RESÚMENES}

La publicación de Burdeos 1972 en 2013 es un acontecimiento fundamental para el estudio de la obra literaria de Mario Levrero : por un lado saca a la luz un texto póstumo y desconocido y, por otro -debido en parte a su publicación conjunta con Diario de un canalla- lo instituye pragmáticamente en la serie autobiográfica del autor. Burdeos 1972 fue escrito luego de La Novela Luminosa, es decir, hasta donde se sabe es el último relato escrito por Levrero aunque el espaciotiempo se remonte treinta años atrás: su viaje y permanencia en Burdeos durante 1972. Duplicación, retrospección y recreación son los procedimientos que Levrero pone en juego en este diario destemplado que reconfigura los estatutos del género, e insiste en la escritura de lo imposible : recuperar el presente a partir del relato del pasado para crear un origen -de su escritura, de sí mismo- y a la vez un final. Si se escribe para recordar y se recuerda para escribir, la paradoja se vuelve un gesto de contemporaneidad tal como lo presenta Giorgio Agamben « esa relación con el tiempo que adhiere a éste a través de un desfase y un anacronismo ».

La publication de Burdeos 1972 en 2013 est un événement fondamental dans les études de l'œuvre littéraire de Mario Levrero. En raison de sa publication simultanée avec Diario de un canalla, ce texte posthume est inscrit dans la série autobiographique. Rédigé après La novela luminosa, Burdeos 1972 est, d'après ce que l'on sait, le dernier récit écrit par Levrero, même si l'espace-temps remonte à trente ans auparavant. Dans ce journal de ce voyage et ce séjour à Bordeaux pendant l'année 1972, Levrero met en jeu deux procédés, rétrospection et récréation, reconfigurant le genre. Il insiste sur l'écriture de l'impossible : récupérer le présent à partir du récit du passé pour créer une origine -de son écriture, de soi-même- et en même temps une fin. Si l'on écrit pour se souvenir et si on se souvient pour écrire, le paradoxe devient un geste de contemporanéité tel que Giorgio Agamben le présente, en tant que « rapport avec le temps à travers le décalage et l'anachronisme ».

The publication of Burdeos 1972 in 2013 is a crucial event. When this posthumous text came to light with the joint publication of the Diario de un canalla, it was thus added to the the autobiographical series of the author. Burdeos 1972 was written after La Novela Luminosa, hence one can assume that it is the last of Levrero's stories, even if its space-time setting is thirty years before his trip and stay in Burdeos in 1972. Duplication, retrospection and recreation are the procedures Levrero uses in this feverish diary which reassembles the rules of the genre, and persists in writing the impossible : Recuperate the present by starting to tell the past in order to create an origin story-of his writing and of himself. If we write in order to remember and we remember in order to write, the paradox becomes a gesture of contemporaneity as presented by Giorgio Agamben « that relationship with time which adheres to it through a discrepancy and an anachronism ». 
ÍNDICE

Mots-clés: littérature latino-américaine, récit autobiographique, journal, pacte de lecture, fiction/témoignage

Palabras claves: literatura latinoamericana, relato autobiográfico, diario íntimo, pacto de lectura, ficción / testimonio

Keywords: latin American literature, autobiographical story, diary, reading pact, fiction / testimony

\section{AUTOR}

CAROLINA BARTALINI

CONICET-UNTREF 